\section{Pitting of Grapefruit that Resembles Chilling Injury}

\author{
Peter D. Petracek \\ Florida Department of Citrus, 700 Experiment Station Road, Citrus Research \\ and Education Center, Lake Alfred, FL 33850
}

\author{
Wilfred F. Wardowski ${ }^{2}$ \\ University of Florida, 700 Experiment Station Road, Citrus Research and \\ Education Center, Lake Alfred, FL 33850
}

G. Eldon Brown

Florida Department of Citrus, 700 Experiment Station Road, Citrus Research and Education Center, Lake Alfred, FL 33850

Additional index words. Citrus paradisi, gas exchange, temperature, wax

\begin{abstract}
A postharvest peel disorder, morphologically similar to chilling injury (CI), was detected on nonchilled 'Marsh' white grapefruit (Citrus paradisi Macf.). Like CI, the disorder was characterized by pitting of the peel caused by the collapse of oil gland clusters. This disorder is distinguished from $\mathrm{CI}$ in that pitting developed within the first 10 days of postharvest storage on fruit held at high (21.0C), but not low (4.5C), temperatures and on waxed fruit, but not unwaxed fruit. Pathogens isolated from pitted fruit were similar to those of nonpitted fruit. No preharvest pitting or visual clues of fruit susceptibility were observed.
\end{abstract}

Chilling injury (CI) of grapefruit is a postharvest peel disorder caused by lowtemperature $(<10 \mathrm{C})$ storage. $\mathrm{CI}$ is characterized by pitting of the peel resulting from the sporadic or widespread collapse of oil glands near the peel surface and the eventual bronzing or necrosis of the affected areas (Grierson, 1986; Whiteside et al., 1988). CI does not necessarily affect internal fruit quality, but may result in increased susceptibility to pathogen invasion and reduced marketability. Although the physiology of CI is not fully understood, the development of $\mathrm{CI}$ is controlled by preharvest factors, such as time of harvest (Kawada et al., 1978), mineral composition (Slutzky et al., 1981), and postharvest treatments, such as high humidity (Purvis, 1984) and application of the fungicide 2-(4-thiazolyl)$1 H$-benzimidazole [thiabendazole (TBZ)] (Kokkalos, 1974; McDonald et al., 1991; Wardowski et al., 1975). In practice, the incidence of grapefruit $\mathrm{CI}$ is reduced primarily by controlling water loss and storing the fruit above chilling temperatures $(>12 \mathrm{C})$ or by conditioning the fruit to progressively lower temperatures during early storage (Chalutz et al., 1985; Eaks, 1960; Hatton and Cubbedge, 1983).

In mid-Feb. 1994, we received inquiries about the cause of pitting of exported white grapefruit. Although the fruit reportedly were not subjected to chilling temperatures, the

Received for publication 22 May 1995. Accepted for publication 24 Aug. 1995. We acknowledge Craig Davis for his help in obtaining the scanning electron micrographs and Diana Wilhite and Lymari Montalvo for their technical assistance. The cost of publishing this paper was defrayed in part by the payment of page charges. Under postal regulations, this paper therefore must be hereby marked advertisement solely to indicate this fact. pitting initially appeared to be morphologically similar to that caused by CI. Preliminary studies showed that pitting occurred only on fruit stored at ambient temperature and thus confirmed that this disorder was not CI. Our objectives were to morphologically characterize this disorder and to determine how this disorder is affected by selected postharvest handling techniques commonly used in the packing of exported white grapefruit.

\section{Materials and Methods}

Plant material. 'Marsh' white grapefruit were harvested from groves in the Martin, St. Lucie, or Indian River counties in Florida. Fruit were packed at the Citrus Research and Education Center (CREC) in Lake Alfred, Fla., or in commercial packinghouses in Lake Hamilton, Haines City, Winter Garden, or Fort Pierce, Fla. All fruit used in these studies were size 36 (10.0 to $11.4 \mathrm{~cm}$ in diameter). Fruit were washed with commercially available citrus washing solutions, comprised of ionic and nonionic surfactants, and waxed with commercially available shellac-based, water-emulsion wax within 1 day of harvest, unless otherwise noted.

Morphology. The time course for the development of pitting was determined by visual inspection of 64 fruit [packed on 18 Apr. 1994 in Lake Hamilton and stored for 15 days at $21.0 \pm 1.0 \mathrm{C}$ at $95 \% \pm 2 \%$ relative humidity (RH)] every 2 or 3 days over 35 days. The numbers of sunken glands and clusters of sunken glands were counted, and newly pitted areas were circled with a marking pen. A similar visual assessment of the pit distribution over the surface of the fruit was made by dividing the fruit into six regions (stylar, stem, and four midsection regions) of about equal area and counting the number of pitted clusters and pitted glands per cluster after 40 days of storage.

Scanning electron micrographs (SEM) of pitted and nonpitted regions from six representative fruit were prepared by freeze-drying the pitted tissue, freeze-fracturing the tissue in liquid $\mathrm{N}_{2}$, and mounting the tissue on aluminum stubs. Samples were gold-coated, examined with a SEM (model S530; Hitachi, Danbury, Conn.) at $10 \mathrm{kV}$ accelerating voltage, and photographed with Polaroid (Cambridge, Mass.) P/N 55 film.

Pathology. The association of pathogens with pitted and nonpitted areas was evaluated by submerging fruit (packed 18 Apr. 1994 in Lake Hamilton and stored for 15 days at 21.0 $\pm 1.0 \mathrm{C}$ at $95 \% \pm 2 \% \mathrm{RH})$ in $70 \%$ ethyl alcohol for $2 \mathrm{~min}$. Fruit then were dried thoroughly with paper towels, and 10 pieces (each about 8 $\mathrm{mm}^{3}$ ) of pitted and nonpitted surface tissue were removed from each of 10 fruit, plated on minimal medium (Brown, 1975), and incubated at $25 \mathrm{C}$ for microbial development and identification.

Effect oftemperature. For preliminary studies on the effect of storage temperature on pitting, fruit were drenched with water containing chlorine $\left(50 \mu \mathrm{g} \cdot \mathrm{ml}^{-1}\right)$ and TBZ (700 $\mu \mathrm{g} \cdot \mathrm{ml}^{-1}$ ) (Merck and Co., Rakway, N.J.), degreened with ethylene ( 5 to $7 \mu \mathrm{g} \cdot \mathrm{ml}^{-1}$ at $29.5 \pm$ $2 \mathrm{C}$ and $93 \% \pm 3 \% \mathrm{RH}$ ) for 48 or $72 \mathrm{~h}$, washed, and waxed with water-emulsion wax containing TBZ $\left(2000 \mu \mathrm{g} \cdot \mathrm{ml}^{-1}\right)$ for fruit packed on 25 Mar. and 18 Apr. 1994 in Lake Hamilton and 13 Jan. 1995 in Winter Garden. Fruit packed on 2 Feb. 1995 at the CREC were not drenched or degreened and no TBZ was used in the wax. Fruit were transferred within $6 \mathrm{~h}$ of packing to storage rooms, adjusted to 4.5 or $21.0 \pm 1.0 \mathrm{C}$ and $95 \% \pm 2 \% \mathrm{RH}$, at the CREC. Fruit (two boxes of 36 fruit per box for each of two treatments) were rated visually ( $0=$ no pits; 1 $=1$ to 3 pits, $2=4$ to 10 pits, $3=11$ to 30 pits, $4=31$ to 100 pits, and $5=$ more than 100 pits) 15 and 40 days after packing. The frequency of pitting was expressed as the percentage of fruit with a rating $\geq 2$.

For a more detailed study on temperature effects on pitting, fruit were drenched with 1,[2-(2,4-dichlorophenyl)-2-(2-propenyloxy) ethyl]-1H-imidazole (imazalil) $\left(250 \mu \mathrm{g} \cdot \mathrm{ml}^{-1}\right.$, Janssen Pharmaceutica, Beerse, Belgium), washed with surfactant solution, and waxed with water-emulsion wax. Fruit (three boxes of 36 fruit per box for each treatment) were packed on 15 Feb. 1995 in Haines City; transported to the CREC within $1 \mathrm{~h}$ of packing; and stored at $4.5,10.0,15.5$, or $21.0 \pm 1.0 \mathrm{C}$ and $95 \% \pm 2 \%$ RH. Fruit stored at $21.0 \pm 1.0 \mathrm{C}$ were transferred to $4.5 \pm 1.0 \mathrm{C}$ at $2,4,8$, or 16 days after packing or to $10.0 \pm 1.0 \mathrm{C}$ at 2,4 , or 8 days after packing. The time required to equilibrate the fruit to storage room temperature was $<6 \mathrm{~h}$, as determined by thermocouple measurement of core temperatures of similarly packed fruit. Fruit were visually rated for pitting 1,7, 13,21, 28, and 35 days after packing.

Effects of degreening, washing, and waxing. For the study on ethylene effects on pitting, fruit (three boxes of 36 fruit per box for 
each treatment) were harvested on 10 Jan. 1995 in Indian River County and were transported to the CREC for packing. The fruit were exposed to ethylene $\left(9 \mu \mathrm{g} \cdot \mathrm{ml}^{-1}\right.$ at $29.5 \pm$ $2.0 \mathrm{C}$ and $93 \% \pm 3 \% \mathrm{RH}$ ) for $0,4,24,48$, or 68 $\mathrm{h}$ and then held $72,68,48,24$, or $4 \mathrm{~h}$, respectively, at $21.0 \pm 1.0 \mathrm{C}$ and $93 \% \pm 3 \%$ RH with no ethylene. Fruit were washed with surfactant solution, waxed with water-emulsion wax, stored at $21.0 \pm 1.0 \mathrm{C}$ and $95 \% \pm 2 \% \mathrm{RH}$, and visually rated for pitting 28 days after packing.

The effects of commercial washing and waxing techniques on pitting were assessed by three factorial studies. Unless otherwise noted, fruit were drenched with water containing chlorine $\left(50 \mu \mathrm{g} \cdot \mathrm{ml}^{-1}\right)$ and TBZ $\left(700 \mu \mathrm{g} \cdot \mathrm{ml}^{-1}\right)$, degreened with ethylene (5 to $7 \mu \mathrm{g} \cdot \mathrm{ml}^{-1}$ at $\approx 30 \mathrm{C}$ and $90 \%$ to $95 \% \mathrm{RH}$ ) for $48 \mathrm{~h}$, and then were either 1) washed with surfactant and waxed, 2) washed with surfactant and not waxed, 3) washed without surfactant and waxed, or 4) washed without surfactant and not waxed. Two boxes of 36 fruit per box were used for each treatment. Fruit were transferred to storage rooms at $21.0 \pm 1.0 \mathrm{C}$ and $95 \% \pm 2 \%$ $\mathrm{RH}$ at the CREC within $6 \mathrm{~h}$ of packing, and pitting was evaluated 15 and 40 days after packing.

In the first study, a commercially available water-emulsion wax formulation was evaluated on fruit packed on 13 Apr. 1994 in Lake Hamilton. In the second study, another commonly used wax, produced by a second company, was evaluated for fruit packed on 26 May 1994 in Fort Pierce. In addition to the four treatments listed, two additional treatments were added: drenched and degreened fruit were 5) not washed but were waxed or 6) not washed and not waxed. In the final study, a third commercially available wax formulation was evaluated on fruit packed on 10 Jan. 1995 at the CREC.

Internal $\mathrm{O}_{2}$ and $\mathrm{CO}_{2}$ levels. A time course on the effect of temperature and waxing on internal gas level was prepared. Fruit were harvested in Indian River County, transported to the CREC, and held overnight at $21.0 \pm 1.0 \mathrm{C}$ and $95 \% \pm 2 \% \mathrm{RH}$. The fruit (six fruit for each treatment) were washed with surfactant, waxed, and held at $1.0,4.5,10,15.5,21.0$, or $29.5 \pm$ $1.0 \mathrm{C}$ and $95 \% \pm 2 \% \mathrm{RH}$. Unwaxed fruit were held at $1.0,4.5$, or $21.0 \pm 1.0 \mathrm{C}$ and $95 \% \pm 2 \%$ $\mathrm{RH}$. Septa were created by applying dabs $(\approx 2$ $\mathrm{cm}$ in diameter) of silicone (3140 RTV; DOW, Midland, Mich.) to the stylar end of the fruit. Gas samples $(0.5 \mathrm{ml})$ were taken by syringe through the septa from the inner core of the fruit $1.5,3,6,12,24,48,144,336,624$, and $792 \mathrm{~h}$ after waxing. Samples were analyzed by a flow-through system, consisting of a paramagnetic $\mathrm{O}_{2}$ analyzer (model 570A; Servomex, Norwood, Mass.) and an infrared $\mathrm{CO}_{2}$ analyzer (model AR-400; Anarad, Santa Barbara, Calif.) connected in series with $\mathrm{N}_{2}$ used as the carrier gas.

\section{Results and Discussion}

Pitting of nonchilled fruit was characterized by clusters of collapsed oil glands scattered over the surface of the fruit (Fig. 1A).

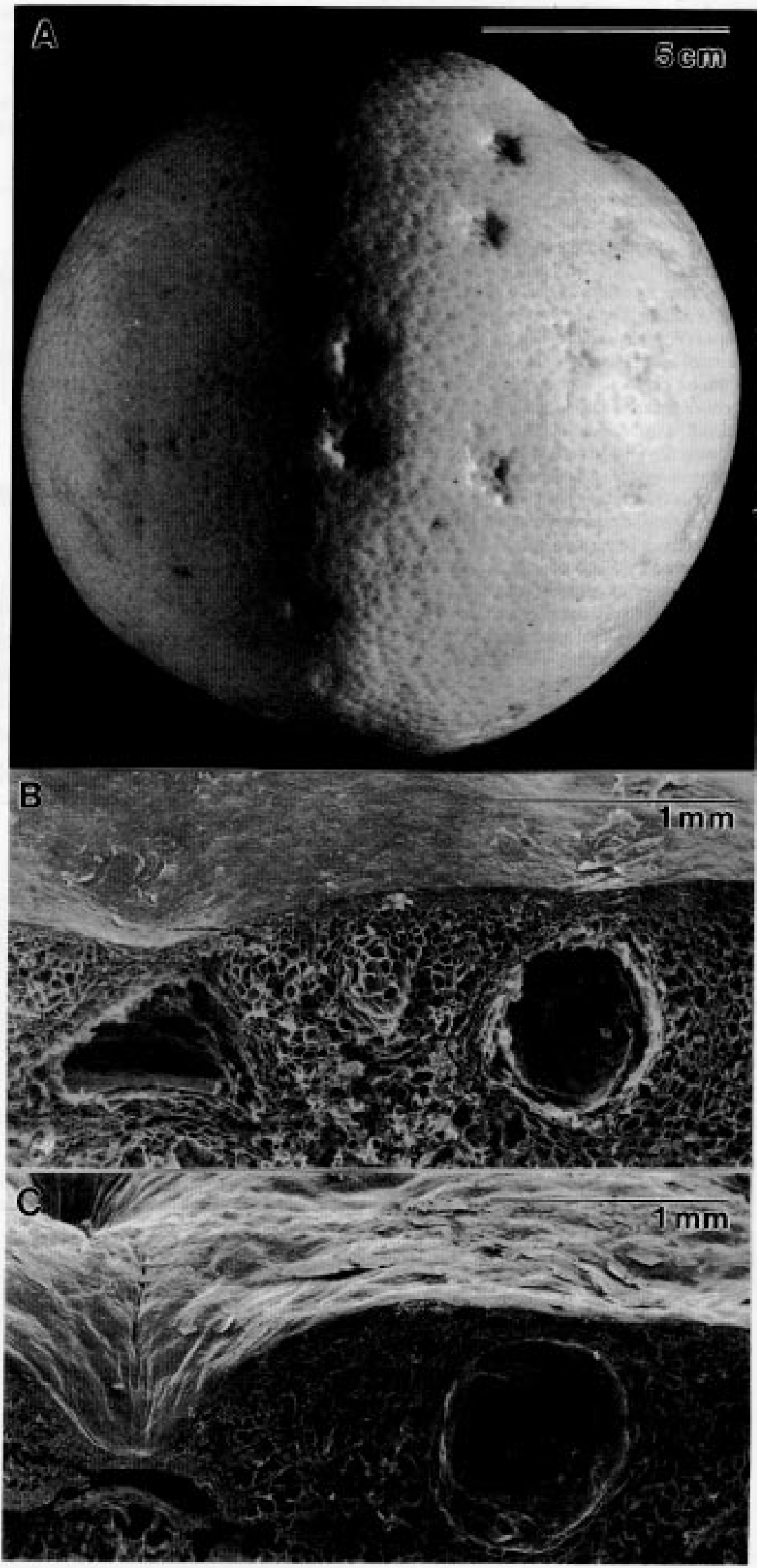

Fig. 1. (A) Pitting of nonchilled 'Marsh' white grapefruit. Scanning electron micrographs of freeze-fractured segments of pitted peel with (B) slight and (C) severe collapse of oil glands. 
The disorder first was expressed as a slight depression of the peel in regions directly above oil glands. These regions often became bronze in color within 3 days after the initial depressions were noted. When two or more adjacent oil glands collapsed, the peel between the oil glands often became indented. In contrast, damage due to $\mathrm{CI}$ tends to be more general rather than focused on oil glands, and discoloration caused by $\mathrm{CI}$ tends to be darker brown and more uniformly distributed between the oil glands.

The severity of the disorder was recorded by SEM and marked by the extent of oil gland collapse (Fig. $1 \mathrm{~B}$ and C). The layers of small epidermal cells between the surface of the fruit and the oil gland, as well as the large albedo cells underlying the oil gland, appeared to be collapsed or disoriented. Portions of the oil gland near the albedo cells were flattened and glands thus appeared deflated. Depression of the outer surface of the fruit was typically 0.1 to $0.3 \mathrm{~mm}$ deep (moderate collapse, Fig. 1B) to $>0.7 \mathrm{~mm}$ deep (complete collapse, Fig. 1C). Complete collapse did not necessarily affect the morphology of adjacent oil glands.

The pits initially appeared as early as 2 days after packing, and appearance concluded about 28 days thereafter. The rate of appearance was highest in the first 2 weeks after packing (e.g., Fig. 2). Susceptibility of the fruit or specific regions on the fruit was not predictable by visual inspection of the fruit before pitting. Industry reports that pitting occurred in the field or appeared within hours after packing were not verified. Pitted areas consisted of an average of three oil glands per cluster (range, 1 to 27). The number of oil glands for a given cluster did not increase with time. The average number of clusters per fruit was 22. Clusters were evenly distributed over the fruit surface with two exceptions: 1) the stem end had $\approx 60 \%$ fewer pits than other regions of the peel, and 2) about a quarter of the midsection region of the peel had few or no pits.

Pitting was not associated with the presence of an isolated pathogen. As many as 70\% and $59 \%$ of the tissue pieces were sterile for pitted and nonpitted regions, respectively. Colletotrichum, the most commonly isolated pathogen, was recovered from $16 \%$ and $25 \%$ of the tissue pieces from pitted and nonpitted regions, respectively. Occasionally, other organisms were isolated ( $<10 \%$ occurrence), including Mycosphaerella, Chaetomium, Penicillium, Candida, and Fusarium, with similar occurrences for pitted and nonpitted regions.

For all studies, postharvest pitting was absent on fruit that were stored at $4.5 \mathrm{C}$ within several hours after packing but was observed on fruit held at 21.0C (Table 1). Detailed evaluation of temperature effects revealed that the rate of pit appearance (Fig. 2) and the extent of pitting (Table 2) were most effectively controlled when fruit were stored at $4.5 \mathrm{C}$ within $1 \mathrm{~h}$ after packing. Storage at $10.0 \mathrm{C}$ or transferring fruit from 21.0 to 4.5 or $10.0 \mathrm{C}$ after 2 days also suppressed pitting, but to a lesser extent. Pitting for fruit stored at low temperature ( 4.5 or $10.0 \mathrm{C}$ ) within 1 hour after packing was primarily due to CI. Pitting was not inhibited by transferring fruit to 4.5 or $10.0 \mathrm{C}$ after 4 or more days of storage at $21.0 \mathrm{C}$ or by storage at $15.5 \mathrm{C}$ (Table 2 ).

Exposure of the fruit to ethylene up to $68 \mathrm{~h}$ before washing and waxing did not affect

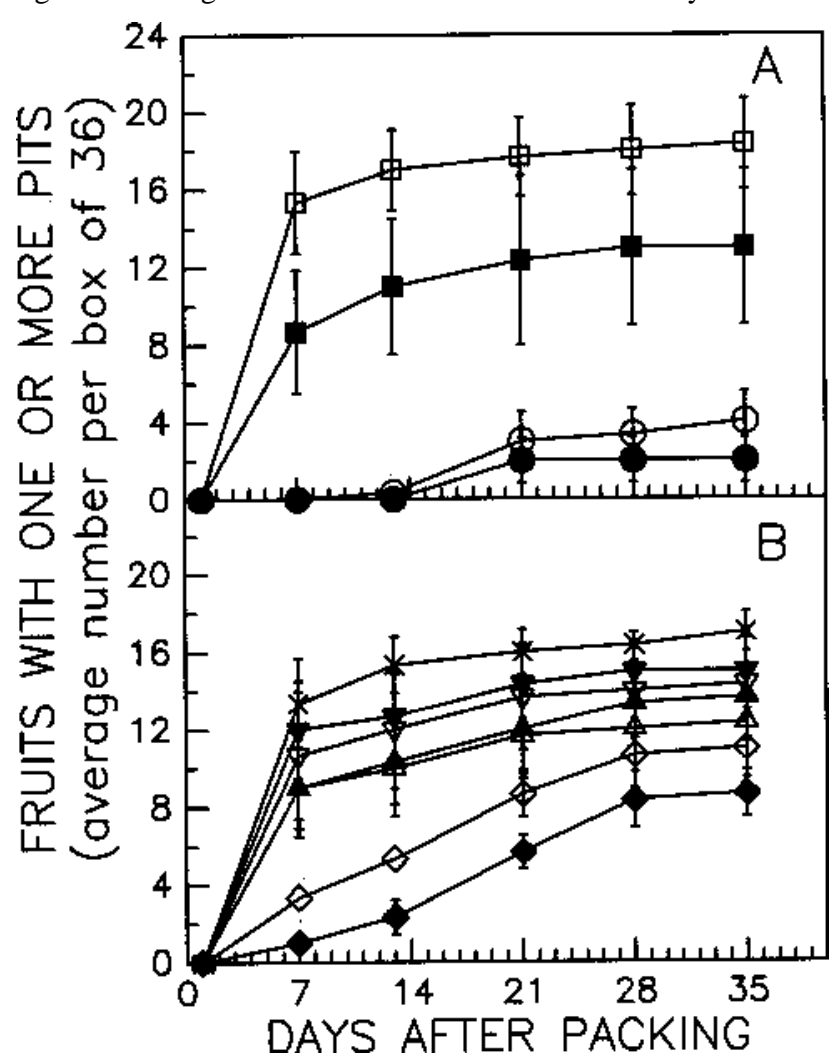

Fig. 2. Effect of storage temperature on the number of grapefruit pits following packing. (A) Fruit stored at constant temperature: $(\mathbf{O}) 4.5$, (○) 10.0 , (口) 15.5 , or $(\square) 21.0 \pm 1.0 \mathrm{C}$. (B) Fruit stored at variable temperatures: $21.0 \pm 1.0 \mathrm{C}$ for $(\diamond) 2,(\boldsymbol{\Delta}) 4,(\nabla) 8$, or $(\times) 16$ days; then at $4.5 \pm 1.0 \mathrm{C}$ or at $21.0 \pm 1.0 \mathrm{C}$ for $(\diamond) 2,(\boldsymbol{\Delta}) 4$, or $(\nabla) 8$ days; and then at 10.0 \pm 1.0C. Symbols represent the mean for three boxes of 36 fruit per box $( \pm \mathrm{SE})$.

Table 1. Effect of storing grapefruit 40 days at 4.5 or $21.0 \mathrm{C}$ following packing on severity of pitting.

\begin{tabular}{|c|c|c|c|c|}
\hline \multirow{3}{*}{$\begin{array}{l}\text { Storage } \\
\text { temp }\left({ }^{\circ} \mathrm{C}\right)\end{array}$} & \multicolumn{4}{|c|}{ Pitting (rating) ${ }^{\mathrm{z}}$} \\
\hline & \multicolumn{4}{|c|}{ Packing dates } \\
\hline & 25 Mar. 1994 & 18 Apr. 1994 & 10 Jan. 1995 & 2 Feb. 1995 \\
\hline 4.5 & $0.0 \pm 0.0(0)$ & $0.0 \pm 0.0(0)$ & $0.0 \pm 0.0(0)$ & $0.0 \pm 0.0(0)$ \\
\hline 21.0 & $1.0 \pm 0.2(28)$ & $1.1 \pm 0.2(24)$ & $0.7 \pm 0.1(15)$ & $1.2 \pm 0.3(25)$ \\
\hline
\end{tabular}

${ }^{2}$ Mean score $( \pm \mathrm{SE})$ for 72 fruit. Pitting was rated from 0 (none) to 5 (most severe). Percentage of fruit with four or more collapsed oil glands is in parentheses.

Table 2. Effect of storing grapefruit 35 days at 4.5, 10.0, 15.5, or 21.0C following packing on severity of pitting.

\begin{tabular}{|c|c|c|}
\hline $\begin{array}{l}\text { Storage } \\
\text { temp }\left({ }^{\circ} \mathrm{C}\right)\end{array}$ & $\begin{array}{c}\text { Storage } \\
\text { pitting (rating) }\end{array}$ & $\begin{array}{c}\text { Incidence of collapsed } \\
\text { oil glands (no.) }{ }^{\mathrm{y}} \\
\end{array}$ \\
\hline$\overline{4.5}$ & $0.1 \pm 0.1 \mathrm{a}$ & $0.7 \pm 0.7 \mathrm{a}$ \\
\hline 10.0 & $0.2 \pm 0.1 \mathrm{ab}$ & $3.0 \pm 2.0 \mathrm{ab}$ \\
\hline 15.5 & $0.9 \pm 0.3 \mathrm{~cd}$ & $10.3 \pm 3.8 \mathrm{bc}$ \\
\hline 21.0 & $1.1 \pm 0.2 \mathrm{~d}$ & $13.0 \pm 3.5 \mathrm{c}$ \\
\hline 21.0 for 2 days, then 4.5 & $0.4 \pm 0.1 \mathrm{a}-\mathrm{c}$ & $5.0 \pm 1.0 \mathrm{a}-\mathrm{c}$ \\
\hline 21.0 for 4 days, then 4.5 & $0.9 \pm 0.2 \mathrm{~b}-\mathrm{d}$ & $10.0 \pm 2.5 b c$ \\
\hline 21.0 for 8 days, then 4.5 & $0.8 \pm 0.2 \mathrm{~b}-\mathrm{d}$ & $8.3 \pm 2.9 \mathrm{a}-\mathrm{c}$ \\
\hline 21.0 for 16 days, then 4.5 & $1.1 \pm 0.2 \mathrm{~d}$ & $12.7 \pm 1.8 \mathrm{c}$ \\
\hline 21.0 for 2 days, then 10.0 & $0.5 \pm 0.2 \mathrm{a}-\mathrm{c}$ & $4.0 \pm 2.6 \mathrm{ab}$ \\
\hline 21.0 for 4 days, then 10.0 & $0.9 \pm 0.3 b-d$ & $9.3 \pm 3.0 \mathrm{bc}$ \\
\hline 21.0 for 8 days, then 10.0 & $0.6 \pm 0.2 \mathrm{a}-\mathrm{d}$ & $6.3 \pm 3.8 \mathrm{a}-\mathrm{c}$ \\
\hline
\end{tabular}

${ }^{2}$ Mean score ( $\pm \mathrm{sE}$ ) for three boxes of 36 fruit per box. Pitting was rated from 0 (none) to 5 (most severe). y Number of fruit per box of 36 with four or more collapsed oil glands. Mean separation within columns by Duncan's new multiple range test at $\alpha=0.05$. 
detrimental effects of applied wax often are related to stimulation of pathogen development (Brown, 1992; Waks et al., 1985) and production of anaerobic off-flavors (Davis and Hofmann, 1973; Hagenmaier and Baker, 1994). Wild (1991) reported peteca rind pitting of lemons [Citrus limon(L.) Burm. f.] was stimulated by waxing, although the cause was not determined. It is unlikely that the pitting observed in our studies was due to a phytotoxic response or "burning" of the peel. Phytotoxic response of citrus peels to wax application is uncommon and reportedly is characterized by localized collapse of the entire peel within several days after waxing. In contrast, the pitting we observed was characterized by scattered collapse of patches of oil glands, which sometimes appeared several weeks after application. We also note that waxes used in our studies came from two companies and consisted of three formulations. Moreover, reports from packinghouses indicated that fruit treated with water-emulsion waxes from other companies also pitted, which indicates that the problem is not associated strictly with one specific wax formulation.

To our knowledge, the effects of wax formulation on pitting have not been evaluated yet. Furthermore, a detailed study on the effects of fungicides that are incorporated in the wax may be beneficial. However, because pitting developed on fruit not treated with fungicide (Table 3, 10 Jan. 1995 packed date), we assume that fungicide treatment is not essential for pitting.

The interaction between temperature and waxing on pitting gas exchange and internal gas compositions may be intermediary factors. Studies on internal gas levels of waxed and nonwaxed grapefruit showed that steadystate $\mathrm{O}_{2}$ and $\mathrm{CO}_{2}$ levels were attained in $\angle 48 \mathrm{~h}$, and the time to attain steady-state conditions decreased with increasing temperature (e.g., $\approx 48 \mathrm{~h}$ at $1.0 \mathrm{C}$ and $6 \mathrm{~h}$ at $29.4 \mathrm{C}$, detailed data not shown). Internal gas levels varied little with temperature for nonwaxed fruit $(18.5 \%$ and $19.5 \%$ for $\mathrm{O}_{2}$ and $0.9 \%$ and $0.7 \%$ for $\mathrm{CO}_{2}$ for 21.0 and $4.5 \mathrm{C}$, respectively) but changed substantially with temperature for waxed fruit (2.5\% and $13.4 \%$ for $\mathrm{O}_{2}$ and $6.0 \%$ and $1.9 \%$

Table 3. Effect of surfactant washing and waxing on pitting of grapefruit held for 40 days at 21.0C after packing.

\begin{tabular}{|c|c|c|c|}
\hline \multicolumn{2}{|c|}{ Treatment } & \multicolumn{2}{|c|}{ Pitting $^{2}$} \\
\hline Washing & Surfactant $^{y}$ & Wax $^{x}$ & No wax \\
\hline \multicolumn{4}{|c|}{13 Apr. 1994} \\
\hline+ & + & $1.5 \pm 0.3(38)$ & $0.0 \pm 0.0(0)$ \\
\hline+ & - & $1.1 \pm 0.2(21)$ & $0.0 \pm 0.0(0)$ \\
\hline \multicolumn{4}{|c|}{6 May 1994} \\
\hline+ & + & $1.0 \pm 0.2(16)$ & $0.0 \pm 0.0(0)$ \\
\hline+ & - & $0.9 \pm 0.1(14)$ & $0.0 \pm 0.0(0)$ \\
\hline- & - & $0.9 \pm 0.1$ & $0.0 \pm 0.0(0)$ \\
\hline \multicolumn{4}{|c|}{10 Jan. 1995} \\
\hline+ & + & $0.9 \pm 0.2(20)$ & $0.0 \pm 0.0(0)$ \\
\hline+ & - & $1.1 \pm 0.2(23)$ & $0.0 \pm 0.0(0)$ \\
\hline
\end{tabular}

${ }^{2}$ Mean score ( $\left.\pm \mathrm{sE}\right)$ for 72 fruit. Pitting was rated from 0 (none) to 5 (most severe). Percentage of fruit with four or more collapsed oil glands is in parentheses. The main treatment of wax application was significant at $\alpha=0.05$ for each packing date.

${ }^{y}$ Surfactants were commercially available solutions comprised of ionic and nonionic surfactants.

${ }^{x}$ Waxes were commercially available, shellac-based, water-emulsion wax formulations. groves were, alternately, pitted extensively or virtually nonpitted, depending on the day harvested, the hour packed, or the mode by which they were shipped. While these reports have been unsubstantiated by experiment, they suggest that fruit susceptibility and postharvest stress may be involved.

We suspect that this disorder has been observed in previous seasons at lower incidence rates and may have been cursorily diagnosed as CI or physical damage. Pitting characterized in this study was distinguishable from CI: 1) CI requires low temperatures $(<10 \mathrm{C})$ to develop, whereas the pitting we observed developed at high temperatures (21.0C); 2) CI is reduced by waxing (Grierson, 1971), whereas pitting required waxing; and 3) CI requires several weeks of storage to develop, whereas pitting developed within the first week of storage.

Pitting is distinguishable from physical damage caused by sand abrasion, puncturing, or insect damage. Physical damage of the peel often is characterized by the presence of a wound periderm and of individual pits or isolated wound areas. Pitting was characterized by scattered clusters of pitted areas with no associated wound periderm. Moreover, physical damage was not always focused on oil glands and does not increase in frequency during storage as is characteristic of pitting.

Other sporadically occurring citrus peel disorders that involve the collapse of oil glands or surrounding areas include rumple or peteca of lemon, "nuxan" blemish of 'Shamouti' orange [Citrus sinensis (L.) Osb.], pitting of 'Pineapple' and 'Valencia' orange, aging, and stem end rind breakdown (Pantastico et al., 1975; Smoot et al., 1971). Further research is required to determine common causal factors between these disorders and the pitting observed for grapefruit. More extensive studies on the influence of storage temperature, wax composition, and changes in peel physiology may explain this newly defined disorder better.

\section{Literature Cited}

Brown, G.E. 1975. Factors affecting postharvest development of Colletotrichum gloeosporioides in citrus fruits. Phytopathology 65:404-409.

Brown, G.E. 1992. Factors affecting the occurrence of anthracnose on Florida citrus fruit. Proc. Intl. Soc. Citricult. 3:1044-1048.

Chalutz, E., J. Waks, and M. Schiffmann-Nadel. 1985. Reducing susceptibility of grapefruit to chilling injury during cold treatment. HortScience 20:226-228.

Davis, P.L. and R.C. Hofmann 1973. Effects of coatings on weight loss and ethanol buildup in juice of oranges. J. Agr. Food Chem. 21:455458.

Eaks, I.L. 1960. Physiological studies of chilling injury in citrus fruits. Plant Physiol. 35:632636.

Grierson, W. 1971. Chilling injury in tropical and subtropical fruits: IV. The role of packaging and waxing in minimizing chilling injury of grapefruit. Proc. Trop. Reg. Amer. Soc. Hort. Sci. 15:76-88.

Grierson, W. 1986. Physiological disorders, p. 361378. In: W.F. Wardowski, S. Nagy, and W. Grierson (eds.). Fresh citrus fruits. Van Nostrand Reinhold Co., New York. 
Hagenmaier, R.D. and R.A. Baker 1994. Wax emulsions and emulsions as citrus coatings. J. Agr. Food Chem. 42:899-902.

Hatton, T.T. and R.H. Cubbedge. 1983. Preferred temperature for prestorage conditioning of 'Marsh' grapefruit to prevent chilling injury at low temperatures. HortScience 18:721-722.

Kawada, K., W. Grierson, and J. Soule. 1978. Seasonal resistance to chilling injury of 'Marsh' grapefruit as related to winter field temperature. Proc. Fla. State Hort. Soc. 91:128-130.

Kokkalos, T.I. 1974. Thiabendazole reduces chilling injury (pitting) of Cyprus-grown grapefruit. HortScience 9:456-457.

McDonald, R.E., W.R. Miller, T.G. McCollum, and G.E. Brown. 1991. Thiabendazole and imazalil applied at 53C reduce chilling injury and decay of grapefruit. HortScience 26:397-399.

Pantastico, E.B., R.A. DeFossard, and H. Safran. 1975. Physiological disorders other than chilling injury, p. 363-391. In: E.B. Pantastico (ed.). Postharvest physiology, handling and utilization of tropical and subtropical fruits and vegetables. AVI, Westport, Conn.

Purvis, A.C. 1984. Importance of water loss in the chilling injury of grapefruit stored at low temperature. Scientia Hort. 23:261-267.

Slutzky, B., A. Gonzalez-Abreu, and I. Berdam. 1981. Chilling injury related to mineral composition of grapefruit and limes during cold storage. Proc. Intl. Soc. Citricult. 2:779-782.

Smoot, J.J., L.G. Houck, and H.B. Johnson. 1971. Market diseases of citrus and other subtropical fruits. U.S. Dept. of Agriculture Agr. Hdbk.
398, U.S. Dept. of Agriculture, Washington, D.C.

Waks, J., M. Schiffmann-Nadel, E. Lomaniec, and E. Chalutz. 1985. Relation between fruit waxing and development of rots in citrus fruit during storage. Plant Dis. 69:869-870.

Wardowski, W.F., L.G. Albrigo, W. Grierson, C.R. Barmore, and T.A. Wheaton. 1975. Chilling injury and decay of grapefruit as affected by thiabendazole, benomyl, and $\mathrm{CO}_{2}$. HortScience 10:381-383.

Whiteside, J.O., S.M. Garnsey, and L.W. Timmer. 1988. Compendium of citrus diseases. APS Press, St. Paul, Minn.

Wild, B.L. 1991. Postharvest factors governing the development of peteca rind pitting on 'Meyer' lemons. HortScience 26:287-289. 